\title{
Godmanhood vs Mangodhood: An Eastern Orthodox Response to Transhumanism*
}

\author{
Dr Brandon Gallaher, University of Exeter
}

Transhumanism is Satanic. When I write this I am not being provocative, let alone vaguely metaphorical. It is meant literally and with the strongest realism. Transhumanism, according to Humanity+ (formerly the World Transhumanist Association), is defined as

(1) The intellectual and cultural movement that affirms the possibility and desirability of fundamentally improving the human condition through applied reason, especially by developing and making widely available technologies to eliminate aging and to greatly enhance human intellectual, physical, and psychological capacities.

(2) The study of the ramifications, promises, and potential dangers of technologies that will enable us to overcome fundamental human limitations, and the related study of the ethical matters involved in developing and using such technologies. ${ }^{1}$

This ideology, alternatively, new 'religion' or 'religious philosophy', 2 of transhumanism, from an Eastern Orthodox perspective, is a systematic elaboration of what various Russian religious thinkers following Dostoevsky (drawing on Feuerbach) called the Luciferan 'religion' of 'Mangodhood' (chelovekobozhestvo and chelovekobozhie) which is characterized by self-worship or the self-deification of humanity. ${ }^{3}$ Mangodhood, it was held, with the man-god or superman as its climax, was

\footnotetext{
* I am grateful to Michael Burdett, Victoria Lorrimar, Ted Peters, Ruth Coates, Gregory Tucker, Marcus Plested, Christopher Sprecher and Regula Zwahlen for help in different ways with this essay.

1 'Transhumanist FAQ', Found at $<$ https://humanityplus.org/philosophy/transhumanist-faq/> (last accessed:2 August 2018).

2 See Tracy J Trothen and Calvin Mercer, eds., Religion and Human Enhancement: Death, Values, and Morality (London: Palgrave Macmillan, 2017), Michael Burdett, Eschatology and the Technological Future (NY/London: Routledge, 2015) and Ted Peters, 'The Future of Transhumanism as a New Religious Movement' (Spring 2014), Found at 〈https://www.youtube.com/watch?v=FLHnEM6B3h A >, (last accessed:3 August 2018).

3 Sergei Bulgakov, 'Heroism and Asceticism: Reflections on the Religious Nature of the Russian Intelligentsia' in eds. And trans. Marshall S. Shatz and Judith E. Zimmerman, Vekhi-Landmarks: A Collection of Articles about the Russian Intelligentsia (Armonk, NY/London: M. E. Sharpe, 1994), pp.17-49 at 26 and The Philosophy of Economy: The World as Household, trans. Catherine Evtuhov (New Haven/London: Yale University Press, 2000), p.149; For commentary see Ruth Coates, 'Feuerbach, Kant, Dostoevskii: The Evolution of "Heroism" and "Asceticism" in Bulgakov's Work to 1909' in Landmarks Revisited: The Vekhi Symposium One Hundred Years On, eds. Robin Aizelwood and Ruth Coates (Boston, MA: Academic Studies Press, 2013), pp.287-307 and Burdett, Eschatology and the Technological Future, pp.213-214.
} 
Satanic in structure and inspiration. It is the mirror inverse of salvation, which is called in Patristic teaching theosis or theopoiesis (divinization/deification) ${ }^{4}$ made possible through the Godman, Jesus Christ, that is, in the famous term of Vladimir Solov'ev, 'Godmanhood' (Bogochelovechestvo). ${ }^{5}$ Nikolai Berdyaev weaves together this dialectic in a characteristic fashion: "Into the religion of God-manhood enters all the plenitude of humanness [...] In man-godhood perishes not only God, but also man [...] The problem of man, the problem of religious anthropology is transformed in the Russian consciousness into the problem about the God-man and the man-god, about Christ and the Anti-Christ.' ${ }^{6}$ In the Russian Silver Age, theosis as 'Godmanhood'7 was understood as the accomplishment by God of the mystery of His embodiment, perfectly realized in Christ, always and in all things. ${ }^{8}$

Mangodhood, in contrast, is an instance of the sort of sham human autodivinization we see in Genesis 3 with the Fall of humanity through its temptation by the serpent who weaves human beings into his ploys by both lies and illusions. Unlike

4 See David Vincent Meconi, The One Christ: St. Augustine's Theology of Deification (Washington, D.C.: The Catholic University of America Press, 2013), Vladimir Kharlamov, ed., Theōsis: Deification in Christian Theology, Volume 2 (Cambridge: James Clarke and Co., 2012), Michael J. Christensen and Jeffery A. Wittung, eds., Partakers of the Divine Nature: The History and Development of Deification in the Christian Traditions (Madison Teaneck: Fairleigh Dickinson University Press, 2007), Stephen Finland and Vladimir Kharlamov, eds., Theōsis: Deification in Christian Theology (Eugene: Pickwick Publications, 2006) and Norman Russell, The Doctrine of Deification in the Greek Patristic Tradition (Oxford: Oxford University Press, 2004).

5 See Jeremy Pilch, 'Breathing the Spirit with Both Lungs': Deification in the Work of Vladimir Solov'ev (Leuven: Peeters, 2018), Oliver Smith, Vladimir Soloviev and the Spiritualization of Matter (Boston, MA: Academic Studies Press, 2011) and Brandon Gallaher, 'The Christological Focus of Vladimir Solov'ev's Sophiology', Modern Theology, 25.4 (October 2009), pp.617-646.

6 See Nikolai Berdyaev, 'Concerning the Character of the Russian Religious Thought of the XIX Century' (1930) [Sovremennye zapiski, 1930, No. 42, pp. 309-343], trans. Stephen Janos, Found at <http://www.berdyaev.com/berdiaev/berd_lib/1930_345.html> (last accessed: 1 August 2018). Also see: 'God-man and man-god -- are polarities of human nature. This involves two paths -- either from God to man or from man to God' (Berdyaev, 'The Revelation about Man in the Creativity of Doestoevsky' (1918) [Russkaya Mysl', March-April 1918, pp.39-61], trans. Stephen Janos, Found at <http://www.berdyaev.com/berdiaev/berd_lib/1918_294.html> (last accessed:1 August 2018).

7 See Ruth Coates, Deification in Russian Religious Thought: Between the Revolutions (1905-1917) (Forthcoming Oxford University Press) (I am grateful to the author for sharing her work with me).

8 See Maximus the Confessor, On Difficulties in the Church Fathers: The Ambigua, 2 vols., ed. and trans. Nicholas Constas (Cambridge: Harvard University Press, 2014), 1: Amb. 7 [PG 91.1084C-D], p.107. 
the case of deification--which assumes the patient, arduous self-work of askesis, cutting back the self, rooting out the passions so that we hope our true self in Christ might flower forth as a divine gift, graciously coming to know the world as God knows it as we come to see Him as $\mathrm{He}$ is and so resemble Him-auto-divinization, and transhumanism is a contemporary instance of this, is the impatient attempt at seizing our divine inheritance before we are ready for its responsibility. One uses all intellectual capacities to split open nature, to manipulate its inner parts to serve us as journeymen gods, elevating ourselves technologically beyond the merely human, and then in a suicidal manner to subsume creation so that all one sees in the cosmos is the idolatrous face of ourselves, like Narcissus tipping into the pool. It is for this reason that Sergii Bulgakov described mangodhood as Satanic, but Satanic precisely as it was both a deception of creation and a pantheistic divinization of the world creating a false Saviour God seen in all forms of modern humanism from Voltaire and Comte to Feuerbach, Nietzsche and Marx:

Pure self-deification, the self-assertion of one's createdness as an absolute is Satanism, a state not immediately accessible to man. The self-assertion of man outside God has the character simply of a conscious divinization of the creature, pantheism or cosmotheism, and is defined only in opposition to theism as atheism or even antitheism, anti-Christianity. This pantheism can have different expressions: the materialism of the Encyclopaedists, the hylozoism of Haeckel, the spiritualistic atheism of Hartmann and Schopenhauer, the economic materialism of Marx, the agnostic positivism of Comte and Spenser. From a religious point of view, however, all of these varieties lead to one and the same content-pantheism or cosmotheism. But this divinization of everything or world-divinization in religious experience inevitably takes on the features of mangodhood. Man is the crown of creation, its king and lord, humanity is a divinity, in which each individual human being participates. And just as the world gives birth to man, so too the task placed before humanity is to give birth to the superman, god. But since humanity only exists in individual persons and everything higher in a man necessarily is personally embodied, this task in its definitive expression amounts to a striving for the giving birth of a single and unique superman, a personal god, that is, the one who is expressed in Christianity as the Antichrist. The unfolding potency, the unavoidable task of mangodhood, is this individual man-god, in whom all of creation would have found its own apotheosis; this idea of an Anti-Christ/Superman has been propounded to modern humanity by Nietzsche. The ultimate meaning of mangodhood amounts to the latter appropriating divinity to itself and proclaiming itself as creation's god. This is the way of Satan, who, not possessing any power of being of his own and in his apostasy from God becoming a spirit of non-being, can only manifest this power by metaphysical theft, since he leads but a ghostly 'meteoric' (in the 
expression of Schelling) existence in constant oscillations between being and nonbeing, and thereby exists only as a deceptive mirage. This mirage would be completely dispelled by an absolute separation of being from non-being, of light from 'outer darkness' [Matt. 8:12, 25:30], which is located on the brink ('edge') of being. ${ }^{9}$

Mangodhood, as Bulgakov has shown us, was and is the trick of the tempter in Genesis 3: that humans might have immediate knowledge of reality (good and evil) like God becoming as gods (3:4-5). This was forbidden not because that knowledge in itself was ultimately impossible for human beings and with it a transformation into what is divine but because it could only come as a gift given, as we shall later argue, from the long trial of loving obedience and dependence of the creature on its Creator modelled in the person of Jesus Christ and the saints who shine with His face. Transhumanism is yet another human/satanic attempt, or, following Bulgakov, we might speak the AntiChrist, at seizing divinity from God, saving and divinizing ourselves but actually in a suicidal fashion tipping ourselves back into the abyss of non-being from which we were created, without what is crucial in order to assimilate the divine into the human: the cross.

There is a common misperception that the pre-modern Christian teaching of theosis, expressed distinctively in the Eastern Orthodox Christian tradition, is somehow restated in a postmodern context in the ideology of transcendence and endless selfimprovement which is transhumanism. ${ }^{10}$ Just as Christians, so the argument goes, have ever strived after a state beyond the human in which not only their fallenness-doing not what they want to do but what they hate to do (Rom. 7:15) - but their very creaturely limitations were transcended, so too now in a contemporary context, using the aid of

\footnotetext{
9 Sergii Bulgakov, Dva Grada: Issledovaniia o priroda obshchestvennykh idealov (St Petersburg: Russian Christian Humanistic Instute Press, 1997), pp.8-9. 10 See discussion in Ronald Cole-Turner, ed., Transhumanism and Transcendence: Christian Hope in an Age of Technological Enhancement (Washington, DC: Georgetown University Press, 2013) and Ted Peters, 'Can We Enhance the Imago Dei' in eds. Nancy Murphy and Christopher C. Knight, Human Identity at the Intersection of Science, Technology and Religion (Aldershot, UK: Ashgate, 2010), pp.215238.
} 
the latest technology, we strive to perfect the human being so that it might become a partaker (2 Pet 1:4), nay, a confector of the divine nature. In this essay, I shall endeavour to distance the classic Eastern Christian Patristic teaching of Eastern Orthodoxy on theosis from this religious philosophy of transhumanism. I will describe critically the transhumanist religion of Mangodhood following it with an account of the very different Orthodox religion of Godmanhood.

\section{Transhumanism: The Religion of Mangodhood}

How do transhumanists generally see the cosmos? Mother Nature is something of a disappointment for many transhumanists. There is no sense of the numinous and the holy here, let alone 'gift' or 'sacrament' as we see in Christianity. Max More is typical here in his 'A Letter to Mother Nature' when he writes to her that 'with all due respect, we must say that you have in many ways done a poor job with the human constitution' by making humans vulnerable to disease and damage, compelling them to age and die, allowing them to function only under narrow environmental conditions and by not giving them better capacity for language, memory etc. One needs to 'amend the human constitution' using biotech in at least seven areas ranging from ending ageing and death to not limiting human capacities 'by remaining purely biological

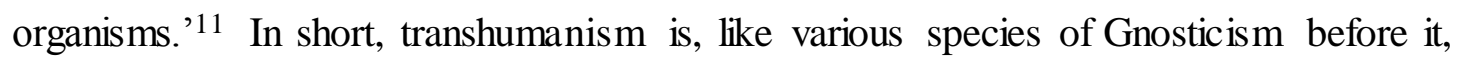
anti-body and anti-creation seeing it as that force which impedes its upwards trajectory, as Simon Young argues: 'As humanism freed us from the chains of superstition, let transhumanism free us from our biological chains.' 12 When pressed to defining just what the 'stuff' of the cosmos might be, transhumanists describe it as 'data' understood

11 Max More, 'A Letter to Mother Nature' in Max More and Natasha Vita-More, eds., The Transhumanist Reader: Classical and Contemporary Essays on the Science, Technology, and the Philosophy of the Human Future (Oxford: Wiley-Blackwell, 2013), pp.449-450.

12 Simon Young, Designer Evolution: A Transhumanist Manifesto (Amherst, NY: Prometheus Books, 2006), p.32 and see Ray Kurzweil, The Singularity is Near: When Humans Transcend Biology (NY: Penguin Books, 2005), p.374. 
as differentiated patterns of information which ultimately means that organisms are described as 'biochemical algorithms.' The same mathematical laws apply to electronic and biochemical algorithms thereby collapsing the distinction between animal and machines: ${ }^{13}$ 'the idea that organisms are algorithms, and that giraffes, tomatoes and human beings are just different methods for processing data.' ${ }^{14}$ As Yuval Noah Harari has observed, we are moving in this vision of the cosmos far beyond humanism, via the view that everything is data, 'from a homo-centric to a data-centric view.' 15 It would seem that creation, and indeed life itself, is just 'data-processing.' 16

'Creation', then, would be a misnomer for how transhumanism sees the universe, as to speak of 'creation' one needs a 'Creator' God and most transhumanists deny there is any supernatural power or god beyond themselves. ${ }^{17}$ They do speak a great deal, for apparently convinced secularists, on ' $\mathrm{g} / \mathrm{God}$ ' but 'God' for them is a sort of superhuman state of 'God-like powers' that might well be attained by a supraintelligent alien civilization at certain points in its evolution and that we humans are ever working/evolving towards going beyond ourselves as humans. ${ }^{18}$ Evolution is a project for transhumanists driven by the 'will to power' of humanity. Indeed, Nietzsche's ideas have been an inspiration for two of the philosophical architects of transhumanism: Max More and Ray Kurzweil. ${ }^{19}$ Evolution is nature transcending itself, for, as Nietzsche observed, 'Man is something that shall be overcome' attaining the

13 Yuval Noah Harari, Homo Deus: A Brief History of Tomorrow (London: Vintage, 2017), p.428.

14 ibid., p.429.

15 ibid, p. 454 .

16 ibid., p.462.

17 Russell Blackford, 'The Great Transition: Ideas and Anxieties' in The Transhumanist Reader, p.421.

18 Giulio Prisco, 'Transcendent Engineering', The Transhumanist Reader, pp.234-235.

19 More, 'The Philosophy of Transhumanism' in The Transhumanist Reader, 10 and Kurzweil, The Singularity is Near, p.373. 
Übermensch: 'Man is a rope, tied between beast and overman-a rope over an abyss. ${ }^{20}$ The self wants to above all 'create beyond itself' by a 'will to power':21

And life itself confided this secret to me: "Behold," it said, "I am that which must always overcome itself. Indeed, you call it a will to procreate or a drive to an end, to something higher, farther, more manifold. ${ }^{22}$

Very often this move from human to man-god or Übermensch is articulated in terms of a highly eccentric vision of evolution borrowing language from both technology and eschatology. ${ }^{23}$ Transhumanism's account of evolution expands upon the a-teleological nature of biological evolution and, in its place is set a conscious willed project of man overcoming nature in some distant parousia. In addition, the transformation of the human to the transhuman is often seen in terms of a future technological Kingdom of Mangodhood--Vernor Vinge and Ray Kurzweil call it the 'Singularity'24_-just beyond the horizon for which all 'singulartarions' must work to realize. ${ }^{25}$ It is, as Martin Rees notes, a sort of futurist version of the Rapture. ${ }^{26}$ Yuval Noah Harari is here illustrative: 'In the twenty-first century, the third big project of humankind will be to acquire for us divine powers of creation and destruction, and upgrade Homo Sapiens to Homo deus [...] We want the ability to re-engineer our bodies and minds in order, above all, to escape old age, death, misery, but once we have it, who knows what else we might do with such ability? So we may well think of the new human agenda as consisting really of one project (with many branches) attaining

20 Friedrich Nietzsche, Thus Spoke Zarathustra in The Portable Nietzsche, ed. and trans. Walter Kaufmann (NY: Penguin Books, 1976), pp.124, 126 (these quotations appear in More and Kuzweil: see n.19).

21 ibid., pp.147, 225.

22 ibid., p. 227.

23 See Burdett, Eschatology and the Technological Future and Technology and the Rise of Transhumanism: Beyond Genetic Engineering (Cambridge: Grove Books Ltd., 2014).

24 Kurzweil, The Singularity is Near, pp.7-9 and More and Vita-More, eds., The Transhumanist Reader, pp.361-417.

25 Kurzweil, The Singularity is Near, pp.370ff.

26 Martin Rees, Our Final Hour: A Scientist's Warning: How Terror, Error, and Environmental Disaster Threaten Humankind's Future in This Century-On Earth and Beyond (NY: Basic Books, 2003), p.19 
divinity.' ${ }^{27}$ One needs to think less of an 'omnipotent biblical sky father' and more in terms of the Greek or Hindu gods who capriciously love, hate, create and destroy like us albeit 'on a much grander scale. ${ }^{28}$ In other words, transhumanists, if they go in for religion or religious talk, do not like any vision of deity that makes a sharp distinction between God and man, the uncreated and the created. ${ }^{29}$

Divinity, Harari tells us, is not anything 'metaphysical' but practically, transhumanist 'divinity' means an exercise of the will through 'specific super-abilities' attained from technology so that the human being and nature itself can be transcended or even left wholly behind including designing and creating new beings, transforming one's body into a cyborg, controlling the environment and the weather, reading minds and communicating at a distance, travelling at very high speeds and escaping death and living indefinitely. ${ }^{30}$ This focus on scientific technique as the path of divinity, that is, the control and manipulation of nature to empower man through the exercise of the will, is no surprise as Francis Bacon (1561-1626) himself, one of the Fathers of the scientific method, saw the task of science as both 'to establish and extend the power and dominion of the human race itself over the universe' and that 'the true and lawful goal of the sciences is none other than this: that human life be endowed with new discoveries and powers', that is, 'lay firmly the foundations and extend more widely the limits of the power and greatness of man.' 31 In envisioning the mangod, the transhumanists argue not only for Intelligence Amplification (IA), perhaps through installing a chip in the brain (connected to wifi for updates), from more memory to better mathematical and

27 Harari, Homo Deus, pp.53-54.

28 ibid., p.54.

29 More, 'The Philosophy of Transhumanism' in The Transhumanist Reader, p.8.

30 Harari, Homo Deus, p.54.

31 Francis Bacon, The New Organon and Related Writings, ed. Fulton H. Anderson, trans. James Spedding, Robert Leslie Ellis and Douglas Denon Heath (NY/London: Macmillan/Library of Liberal Arts, 1960), p.118 (I.CXXIX), p.78 (I.LXXXI), p.106 (I.CXVI); See Burdett, Eschatology and the Technological Future, pp.12-18. 
linguistic skills, more 'emotional intelligence' and even as yet unimagined carnal facility. This is what has led to Gerald McKenny speaking of enhancement technologies as 'technologies of desire' not need, and thereby 'technologies of excess.' 32 In response, some theoreticians have tried to imagine how technology might make us good and hypothesize how 'it might be possible to use biotechnology in a manner that would promote virtue, and thus serve as a means to improve ourselves, morally speaking. ${ }^{33}$

But the ultimate quest for transhumanists past and present has been to synthesize immortality. Indeed, Bacon, in his The History of Life and Death (1638), drew up a systematic history of corporeality in the quest to isolate relevant forms that might lead to immortality at best. More realistically he thought that future scientists 'will become the instruments and dispensers of God's power and mercy in prolonging and renewing the life of man $[\ldots]$ [and that] these our shoes and garments (I mean our frail bodies) are as little worn out as possible. ${ }^{34}$ Later in the $19^{\text {th }}$ century, the eccentric Russian philosopher Nikolai Fedorov (1828-1903) held that the general resurrection did not follow upon the resurrection of Christ because it was the conscious 'Common Task' of humanity that constitutes the 'essence of Christianity' to bring about the selfconsciousness of the Earth over the force of other celestial bodies and involve them in a single life-giving force of resuscitation' of all things in the universe ${ }^{35}$ thereby

32 Gerald P. McKenny, 'Technologies of Desire: Theology, Ethics, and the Enhancement of Human Traits', Theology Today, 59.1 (April 2002), pp.90-103 at 100.

33 Mark Walker, 'Enhancing Genetic Virtue: A Project for Twenty-first century humanity?', Politics and Life Sciences, 28.2 (September 2009), pp.27-47 at 30.

34 Bacon, The History of Life and Death or The Second Title in The Natural and Experimental History For the Foundation of Philosophy: Being the Third Part of the Instauratio Magna in The Works of Francis Bacon, eds. and trans. James Spedding, Robert Leslie Ellis and Douglas Denon Heath, 14 vols. (London: Longmans \& Co., 1861 [1857-1874]), Vol. V: p.215.

35 Nikolai Fedorovich Fedorov, The Philosophy of the Common Task in What as Man Created For?: The Philosophy of the Common Task, eds. and trans. Elisabeth Koutaissoff and Marilyn Minto (Bath/Lausanne: Honeyglen Publishing/L'Age D’Homme, 1990), Part III, p.80; cf. Burdett, Eschatology and the Technological Future, pp.18-24. 
producing paradise or the Kingdom of God on earth. ${ }^{36}$ In recent times, this ancient quest has resulted in a whole class of scientific transhumanists whose goal is to 'Live Forever or Die Trying' (the unofficial motto of scientist Bill Andrews' Reno based biotech company Sierra Sciences that aims 'to extend the human lifespan and healthspan'). ${ }^{37}$ The more flamboyant English but California based anti-ageing activist Aubrey de Grey regularly cites 1000 years as the amount of time that people will live to 'within decades' (transhumanists always say their grand technological predictions will take place in a decade' or 'within decades'). ${ }^{38}$

Besides conquering death, transhumanists also have entertained 'whole brain emulation' or 'uploading' the content of one's brain ('mind', 'self' etc.)--which assumes the brain is hardware and the mind is software--to computers and the internet ${ }^{39}$ and working out of the power of 'morphological freedom' 40 one could then exist in the future not just in a biological mode but a virtual one where one can freely change one's form virtually, ${ }^{41}$ which Ray Kurzweil calls 'human body 3.0.'42 As the quest to live indefinitely seems to recede year on year despite all the technological boostering, the buffer solution is to preserve human cadavers in low temperature preservation for future 'reanimation' (=cryonics) ${ }^{43}$ when technology finally catches up with death. Transhumanism takes in various sciences including nanotechnology, biological

\footnotetext{
36 Fedorov, 'Supramoralism or general synthesis (universal union') in What was Man Created For?, pp.132-133.

37 'Sierra Science: Biotech for Enhanced Living', Found at $<$ https://www.sierrasci.com/about_us $>$ (last accessed: 3 August 2018) and see the documentary, Found at 'The Immortalists', <http://theimmortalists.com/> (last accessed:6 August 2018).

38 Kira Peikoff, 'Anti-Aging Pioneer Aubrey de Grey: "People in Middle Age Now Have a Fair Chance"”, 30 January 2018, Found at <https://leapsmag.com/anti-aging-pioneer-aubrey-de-grey-peoplemiddle-age-now-fair-chance/> (last accessed:2 August 2018).

39 See Nick Bostrum, Superintelligence: Paths, Dangers, Stategies (Oxford: Oxford University Press, 2017), pp.35-43, Ralph C. Merkle, 'Uploading' in The Transhumanist Reader,pp.157-164 and Kurzweil, The Singularity is Near, 198-203.

40 'Transhumanist Declaration' (2012) in The Transhumanist Reader, p.55.

41 See More, 'The Philos ophy of Transhumanism', pp.7-8, 15.

42 Kurzweil, The Singularity is Near, p.310.

43 See 'Alcor Life Extension Foundation: Cryonics', Found at $<$ https://alcor.org/> (last accessed: 2 August 2018)
} 
engineering, cyborg engineering, the engineering of non-organic beings (these latter three take in biotechnology, information technology and cognitive science), but all of these scientific areas presuppose the question for AI which is now called machine 'superintelligence' ${ }^{34}$, which leads many commentators to use 'bio-tech' as a synonym for the transhumanist quest.

The relentless focus on 'intelligence', human or artificial, is ultimately what reveals the true diabolical shape of transhumanism as the religion of mangodhood for it elevates the human being to the focus of everything as a sort of supreme divine EGO. Kurzweil envisions that in the Sixth and Final Epoch of evolution human intelligence 'will begin to saturate the matter and energy in its midst' and spread out from the earth to take over all parts of the universe: 'we will within this century be ready to infuse our solar system with our intelligence through self-replicating non-biological intelligence. It will then spread out to the rest of the universe.' 45 This universe that will eventually become conscious is God for Kurzweil ${ }^{46}$ Transhumanism, as Bulgakov has shown, ends in pantheism. Harari calls it the religion of 'Dataism' with God as 'the Internet-of-AllThings. ${ }^{47}$ But the deity being adored here is the human being as artificial god tricked once again by Satan into seizing its divine inheritance before it was ready for so great a responsibility.

\section{Godmanhood: Creation, Salvation and Human and Divine Action ${ }^{48}$}

But how does Orthodoxy, the vision of Godmanhood, differ from the Mangodhood of Transhumanism? If Transhumanism begins with the perceived failure

44 See Bostrum, Superintelligence,p.26.

45 Kurzweil, The Singularity is Near,pp.21, 372; Compare Bulgakov (The Philosophy ofEconomy, n.10, p.303) on Fichtean ideas of nature becoming reorganized by human intelligence.

46 Kurzweil, The Singularity is Near, p. 390.

47 Harari, Homo Deus, pp.428-462.

48 For a more detailed account see Gallaher, 'Creativity, Covenant and Christ' in God's Creativityand Human Action: Christian and Muslim Perspectives, eds. Lucinda Mosher and David Marshall (Washington, DC: Georgetown University Press, 2017), pp.79-99. 
of creation to live up to the divine aspirations of humanity then Orthodoxy begins with gratitude for God's gift of creation as a living Sacrament of His presence. Creation, moreover, as a gift need not have been created. God does not 'need' it. He could have acted otherwise than He has in fact acted, but, yet creation is not 'accidental' or merely arbitrary. It is created as a fitting and appropriate (but wholly unequal) partner for God in an exchange of love and joy with its Creator who wishes to shower out His blessings upon another. Maximus the Confessor expresses this well:

God, full beyond all fullness, brought creatures into being not because He had need of anything, but so that they might participate in Him in proportion to their capacity and that He Himself might rejoice in His works (cf. Ps. 104:31), through seeing them joyful and ever filled to overflowing with His inexhaustible gifts. ${ }^{49}$

There is, therefore, most certainly, unlike transhumanism, a firm distinction between the uncreated Creator God and the created creation whose pinnacle is the human being. However, Orthodoxy does not thereby alienate God from creation. Nor does it need to collapse the two-like transhumanism-ending in pantheism. The distinction of God and creation in practice is tension-filled as the creature is continually striving beyond its created capacity to participate in the divine which God graciously enlarges. ${ }^{50}$ Thus we participate in God to a greater or lesser degree according to our God given capacity. ${ }^{51}$ But how do we participate in Him?

God creates, sustains and reveals Himself in the cosmos not in any distant fashion but most intimately through His multiple divine uncreated energies which are His dynamic and essential activity since energies are the activity of a nature (here the divine nature): 'God both is and is said to be the nature of all beings, in so far as all

49 Maximus the Confess or, 400 Chapters on Love, 3.46 [PG 90, 1029C] in The Philokalia, 5 vols., trans. G. Palmer, Philip Sherrard, Kallistos Ware, Vol. 2 (London: Faber \& Faber, 1979-1995), p.90.

50 See Maximus the Confessor, On Difficulties in Sacred Scripture: The Responses to Thalassios, trans. Maximos Constas (Washington, DC: The Catholic University of America Press, 2018), 22.7, p.153.

51 Gregory Palamas, Topics of Natural and Theological Science and on the Moral Ascetical Life: 150 Texts', $\$ 69$ in The Philokalia,4: p.378 
partake of Him and subsist by means of this participation: not, however, by participation in His nature--far from it--but by participation in His energy.' ${ }^{52}$ The energies are personal insofar as they are the eternal unified activity of the Father, Son and Holy Spirit but we can experience them in the world through the one through whom God works in all things and who utilizes the energies: the Holy Spirit ${ }^{53}$ who is 'everywhere present and filling all things', as a well-known Eastern Orthodox daily prayer expresses it. These energies pervade the creation but are not identical with it and through them a creature can participate graciously, consciously and through ascetical labours in God and become divinized. They are never separated from the divine essence because they are the personal activity of God in the world, but, while the energies, as they are 'indivisibly divided and multiple' 54 in creation, are accessible, the essence is indivisible and therefore inaccessible and unknowable to creatures. ${ }^{55}$

The human being, like transhumanism, is the pinnacle of creation, the crown for Orthodoxy. However, this 'kingship' of creation assumes a special relationship of loving dependence on God the Creator which is something totally alien to transhumanism, founded as it is on hubristic autodivinization. One of the traditional ways this uniqueness of humanity is expressed is by talking about the image and likeness of God (Gen. 1:26-27). The source of the potential "godhood" of man, then, is a reference to another who is his source and on whom he always depends. The divine image has often been interpreted in terms of how the human being is given 'the superiority of reason' ${ }^{56}$ but reason was not just understood in terms of discursive

52 ibid., $\$ 78$, p. 382

53 ibid., $\$ 75$, p. 380 and $\$ 129$, p. 407 .

54 ibid., $\$ 69$, p.378.

55 ibid., §74, p.380.

56 Basil ofCaesarea, 'First Homily: On the Origin of Humanity, Discourse 1: On that which is according to the Image' in On the Human Condition, trans. Nonna Verna Harrison (Crestwood, NY: St Vladimir's Seminary Press, 2005), §7, p.36. 
rationality ${ }^{57}$ but freedom and creativity. ${ }^{58}$ It was thought to be paralleled by the fact that the human being, of all animals, was created upright so it might look up to see God, whom he resembled, worshipping Him and acknowledging Him as His source and origin and not being 'be dragged down to earth': 'his head is lifted high towards things above, that he may look up to what is akin to him., 59

But to be made to be in free conscious communion and union with God is to be formed in through and for Jesus Christ (Col. 1:16) and it is for this reason that Irenaeus of Lyons writes that the human being was made in the 'image of Christ. ${ }^{60}$ Irenaeus, and other Greek Fathers after him, elaborated on this idea by distinguishing between the image and the likeness of God. For Irenaeus, Adam is created by Christ and for Christ in the initial position as body and soul animated by a breath of life from God's Spirit. ${ }^{61}$ He understands "image" as in reference to the Son, as the image of the invisible God (Colossians 1:15), ${ }^{62}$ whereas "likeness" he understands as in reference to the Spirit who is referred to as God's "figure."63 The image of God might be understood as free, rational and creative personhood with the innate possibility of partaking in conscious fellowship with God in Christ and the likeness of God is an achieved reality when the image, by direct communion with the Person of the Word of God, Jesus Christ, is transformed into the finite image of the divine life.

57 Augustine of Hippo, The Literal Meaning of Genesis: Volume I [De genesi ad litteram liber imperfectus], 3.20.30, trans. John Hammond Taylor, ACW 41 (New York: Paulist Press, 1982), p.96. 58 See Basil of Caesarea, 'Homily on Psalm 48', 8, Exegetic Homilies, trans. Agnes Way, FC 46 (Washington: The Catholic University of America Press, 1963), 311-31 at 324-25 [PG 29b.449B-C] and John of Damascus, Orthodox Faith in St John of Damascus: Writings, 2.30, trans. Frederic H. Chase (Washington: The Catholic University of America Press, 1981), pp.264-265.

59 Basil of Caesarea, 'Second Homily: On the Origin of Humanity, Discourse 2: On the Human Being' in On the Human Condition, $§ 15$, p.61.

60 Irenaeus of Lyons, On the Apostolic Preaching [=Dem.], trans. John Behr (Crestwood, NY: St Vladimir's Seminary Press, 1997), §22 and see 2 Cor. 4:4.

61 Irenaeus of Lyons, Adversus omnes Haereses [=AH]/Contre les Hérésies, (1965-1982), Sources Chrétiennes, trans., ed. Adelin Rousseau et al. (Paris: Cerf, 1965-82), 5.1 .3 and 12.1.

62 Dem. 22 and $A H 5.16 .2$ and compare 2 Cor. 4:4.

63 figuratio (ibid., 4.7.4). ANF translates as similitude; cf. ibid., 5.6.1. 
The human being, then, was made, with creation, to be united with God in Jesus Christ. One way of putting this is to think of one unitary divine plan. Here there is no 'Plan B.' The human being, for Irenaeus, was made for salvation which is 'a second creation by means of His passion which is that [creation] out of death. ${ }^{64}$ Jesus Christ, as the eternal Word of God and Creator, not only precedes the created, but He precedes the created precisely as its Saviour, which means that the created is, not only at the end after the Fall, but at the beginning prior to the Fall, understood as that which will be saved, as Irenaeus put it: 'Since he pre-existed as one who saves, it was necessary that what might be saved also be created so that the one who saves might not be in vain. ${ }^{65}$ Maximus the Confessor understood this idea of man being foreordained for union with God slightly differently by seeing one divine plan but with different modes. God, he argued, planned from before the ages that 'we should exist in Him' and through participation being 'imbued with the exact characteristics of His goodness' ${ }^{66}$ In this way, man might be a 'God by grace' through God coming to 'reside in all beings in a manner appropriate to each' by the many converging 'around the one human nature' so that 'God will be all things in everything, encompassing all things and making them subsist in Himself. ${ }^{97}$ Adam was, therefore, called in this way to be a mediator of the different extremes of creation synthesizing them into unity and drawing them up into union with their Creator. It is precisely because humanity can unite the extremes that he was created last as a 'kind of natural bond mediating between the universal extremes through his parts. ${ }^{68}$ The human being, therefore, unlike transhumanism, is not only the king of creation but also a servant or caretaker of it and called to unify and perfect it in

64 ibid., 5.23.2.

65 'Cum enim praeexsisteret saluans, oportebat et quod saluaretur fieri, uti non vacuum sit saluans' (ibid., 3.22.3).

66 Maximus the Confessor, 1: Amb. 7 (PG 91.1097C), p.133.

67 ibid., 1: Amb. 7 (PG 91.1092C), p.121.

68 ibid., 2: Amb. 41 (PG 91.1304D-1305B), pp.102-105. 
synergy with the Creator. Now had this 'first covenant [of Adam] [...] remained blameless, there would have been no occasion for a second' so that the mystery accomplished in Christ's incarnation is nothing other than 'proof and fulfilment of the mystery which our forefather failed to attain at the beginning of the age. ${ }^{\prime 69}$ In other words, God would have become incarnate even if there had been no Fall. The incarnation was the 'blessed end for which all things were brought into being' since 'for the sake of Christ - that is, for the whole mystery of Christ - that all the ages and the beings existing within those ages received their beginning and end in Christ.' 70

In the story of the Fall, the human being turned from this vocation of uniting heaven and earth in himself. Adam 'misused his freedom' turning in desire from the good which was permissible 'to what was inferior' which was forbidden so freely becoming estranged from the 'divine and blessed goal' which was to be a 'God by grace' and instead ending up to be 'a pile of dust. ${ }^{71}$

It would be a mistake to think, however, that the religion of Godmanhood was somehow anti-science and anti-knowledge and wishes Man to know only what fits his lowly station in comparison to the religion of Mangodhood which celebrates human beings having the ultimate knowledge of reality as God ('you will be like God, knowing good and evil' (Gen. 3:5)). In fact, many Fathers taught that there was nothing in and of itself wrong with Genesis 3's 'knowledge of good and evil.' What was wrong was seizing that knowledge before the human being was mature enough to assimilate it and without a loving obedience and dependence on God, which is precisely what we have argued is the mistake of transhumanism. That is indeed death as it was directly contrary

69 ibid., 1: Amb. 7 (PG 91.1097D), p.133.

70 Maximus the Confessor, Responses to Thalassios, 60.3-4, pp.428-429 and see ibid., 22.2, p.150.

71 Maximus the Confessor, 1: Amb. 7 (PG 91.1092C-D). 
to the express word of God (Gen 1:16-17, 3:2-3) and to be in communion with Him was life. This was the ruse of Satan, as Ephrem the Syrian writes:

He deceived the husbandman so that he plucked prematurely

the fruit which gives forth its sweetness only in due season

--a fruit that, out of season, proves bitter to him who plucks it.

Through a ruse did the serpent reveal the truth,

knowing well the result would be the opposite, because of their presumption;

for blessing becomes a curse to him who seizes it in $\sin ^{72}$

The tree of knowledge of good and evil is, Gregory Nazianzus tells us, 'contemplation' and was not planted 'in an evil way nor forbidden through envy' as the serpent opined but contemplation 'would be good if possessed at the right time' and 'only safe for those of perfect disposition' but death for those who are simple and 'greedy in their desire.' ${ }^{73}$ The tree, Maximus the Confessor likewise contends, when 'spiritually contemplated' possesses the knowledge of good, but when received in a 'corporeal manner' leads to evil and death as it becomes 'the teacher of passions, making them oblivious to divine realities. ${ }^{74}$ Had humanity rejected the serpent's appeal then in time humanity would have eaten of the Tree of Knowledge, it no longer being withheld from them, and from it they would have acquired, as transhumanism now seeks without God and by its own will, 'infallible knowledge' and from the Tree of Life 'immortal life' and they would have 'acquired divinity in humanity.'75 Having 'already become God through divinization' man might have been able to examine 'with God the

72 Ephrem the Syrian, Hymns on Paradise, trans. Sebastian Brock (Crestwood, New York: St. Vladimir's Seminary Press, 1990), Hymn XII. 3, p.161.

73 Gregory Nazianzus, 'Oration 45: On Holy Pascha' in Festal Orations, trans. Nonna Verna Harrison (Crestwood, NY: St Vladimir's Seminary Press, 2008), 45.8, p.167.

74 Maximus the Confessor, Responses to Thalassios, 'Introduction', 1.2.18, p.87.

75 Ephrem the Syrian, The Commentary on Genesis, Section 2, §23 in Hymns on Paradise, p.214 
creations of God' and come to know them 'not as man but as God' since they would have had by grace the very 'same wise and informed knowledge of beings that God has, on account of his intellect and powers of perception. ${ }^{76}$ The serpent by convincing humanity to disobey God 'withheld divinity from them by means of the divinity which it promised them, and it brought about that those, to whom it had promised enlightenment from the Tree of Knowledge, should not have their eyes illumined by the Tree of Life as promised.' 77 This is precisely why we have argued that transhumanism is simply Satanic as it falls into the age-old ruse of the Evil One in seizing divinity for itself and thereby losing it forever.

This vocation of being partakers of the divine nature is, Orthodoxy teaches, reattained in Jesus Christ and specifically in, by and through His death. Here we see yet another difference from transhumanism which attempts to eliminate death technologically. The religion of Godmanhood, in contrast, sees death in Christ as the only sure path to a truly eternal life. In the famous formula of Irenaeus, God in Christ 'became what we are in order that He might make us what He is Himself. ${ }^{78}$ Christ both reopens the door and sets the pattern of our own divinization. His own 'unfathomable self-emptying' in taking human flesh and obedience even unto death on a cross was 'brought about for the deification of our nature.' 79 As Athanasius of Alexandria famously put it: 'For he became man that we might become divine; and he revealed himself through a body that we might receive an idea of the invisible Father; and he endured insults from men that we might inherit incorruption. ${ }^{80}$ Through His life, death and resurrection we are given eternal life through participating in that deifying death

76 Maximus the Confessor, Responses to Thalassios, 'Introduction', 1.2.18, p.87.

77 Ephrem the Syrian, The Commentary on Genesis, Section 2, §23, p.214.

78 Irenaeus, $A H$ V.pref.

79 Maximus the Confessor, 'On the Lord's Prayer' in The Philokalia, 2: p.286.

80 Athanasius of Alexandria, On the Incarnation, $\$ 54$ in Contra Gentes and De Incarnatione, ed. and trans. Robert W. Thoms on (Oxford: Clarendon, 1971), p.269. 
and resurrection through our baptism into His body the Church and conforming to His cruciform and resurrected shape through His Spirit by our anointing in Chrismation. These are renewed every time we receive the Eucharist, consuming the body and blood of the crucified and resurrected Lord and thereby entering into the deifying mystery of life through death. The pattern of life, death and resurrection is the pattern of our liberation from sin and death and our ultimate divinization:

For through His passion He conferred dispassion, through suffering repose, and through death eternal life. By His privations in the flesh He re-established and renewed the human state, and by His own incarnation He bestowed on human nature the supranatural grace of deification. ${ }^{81}$

Yet one cannot appropriate the deifying gift of Christ without obedience, humility and repentance, without, profound acknowledgement of our dependence on God, 'for it is by warfare the soul makes progress': 'Give blood and receive the Spirit., 82 The self-humiliation of God even unto death on the cross which leads to our deification sets the pattern of the whole spiritual life as an unceasing 'salvific labour of asceticism' or spiritual training for the life to come that involves 'extract[ing] the nails of desire, which fasten us to sensual pleasure' thereby learning 'self-mastery' and becoming 'genuine disciples of virtue' ever bent on the 'devotion to the Beautiful. ${ }^{93}$ In working upon the self ascetically one strives for a state of stillness before God ceaselessly calling upon the name of Jesus in the Prayer of the Heart: 'Stillness is unceasing worship and waiting upon God. Let the remembrance of Jesus be present with each breath, and then you will know the value of stillness. ${ }^{84}$ Transhumanism, as we saw earlier, sees the transformation of the human being into a god as a purely external process of technical

81 Maximus the Confessor, 'Various Texts on Theology, the Divine Economy, and Virtue and Vice' in in The Philokalia, 2: Fourth Century, §43, p.246.

82 The Sayings of the Desert Fathers: The Alphabetical Collection, $2^{\text {nd }}$ Ed., trans. Benedicta Ward (Kalamazoo, Mich.: Cistercian Publications, 1984), John the Dwarf, §13, p.88 and Longinus, §5, p.123. 83 Maximus the Confessor, 1: Amb. 13 (PG 91.1209A-B), p.351

84 John Climacus, The Ladder of Divine Ascent, $2^{\text {nd }}$ Ed., trans. and ed. Lazarus Moore (Boston: Holy Transfiuration Monastery, 2001), 27.60-61, p.207. 
exertion of the will upon the self (seen in the most materialist fashion as the body and brain). There is no prayer and contemplation here. In stark contrast, Orthodoxy or the religion of Godmanhood sees salvation in light of a sort of prayerful science of selftransformation through interior self-work. The heart or soul is the focus of the religion of Godmanhood not, as in Mangodhood, the brain:

The heart itself is but a small vessel, yet there also are [there] dragons and there are lions; there are poisonous beasts and all the treasures of evil. And there are rough and uneven roads; there are precipices. But there is also God, also the angels, the life and the kingdom, the light and the apostles, the treasures of grace - there are all things. ${ }^{85}$

As we said above, only repentance for our sins, obedience and humility lead to the 'dispassion that deifies' (apatheia). ${ }^{86}$ The heart of cultivating dispassion is the cutting out or complete renunciation of your own will in all things- 'distrust of oneself in everything, however good it may be, right to the end of one's life'-so that one's will might be reborn in God's will. ${ }^{87}$ The monastic tradition saw this 'tomb of the will and the resurrection of humility' ${ }^{\prime 8}$ as only taking shape in our complete surrender to another in obedience, in this case, a spiritual Father or Mother, whose direction (i.e. will) is taken as being from God: 'Blessed is he who mortifies his will to the end, and leaves the care of himself to his director in the Lord; for he will be placed at the right hand of the Crucified.' ${ }^{89}$ The religion of Mangodhood/transhumanism, in contrast, begins with the will to power over creation. John Climacus describes the ascetical 'narrow way' leading to deification:

The following will show you what the narrow way means: mortification of the stomach, all-night standing, water in moderation, short rations of bread, the purifying draught of dishonour, sneers, derision, insults, the cutting out of one's will, patience in annoyances, unmurmuring endurance of scorn, disregard of insults, and the habit, when wronged, of bearing it sturdily; when slandered, of not being indignant; when

85 Pseudo-Macarius, The Fifty Spiritual Homilies and the Great Letter, ed. and trans. George A. Maloney (NY/Mahwah, Paulist Press, 1992), Hom. 43.7, p.222.

86 St Theognostos, 'On the Practice of the Virtues, Contemplation and the Priesthood', in The Philokalia, 2: $\$ 25$, p.364.

87 John Climacus, The Ladder of Divine Ascent, 4.5, p.22.

88 ibid., 4.3, p.21

89 ibid., 4.44, p.38 
humiliated, not to be angry; when condemned, to be humble. Blessed are they who follow the way we have just described, for theirs is the Kingdom of Heaven. ${ }^{90}$

We have just been describing what is generally called the first stage of the spiritual path, the purgative, which is for beginners and involves 'spiritual warfare' 91 whereby through cutting out the will and putting death to the passions one is crucified to the world and the world to oneself, following the example of Christ (Gal. 6:14) and in this way receiving eternal life through death. ${ }^{92}$ After it, for the mature, follows the 'illuminative' stage when being freed from dispassion, one has, through the Spirit, a 'spiritual knowledge of created beings.' 93 Finally, one arrives at the 'mystical and perfective stage'-deification proper-where one comes to the 'measure of the stature of the fullness of Christ' (Eph. 4:13) and one is initiated into the 'hidden mysteries of God and our being filled with ineffable wisdom through union with the Holy Spirit. ${ }^{94}$ But how has deification, this last perfective stage, been characterized?

\section{Godmanhood: Deification}

Theosis, as should now be clear, underlies almost every aspect of Orthodoxy as the religion of Godmanhood. It is not some additional extra but the presupposition of all doctrine, worship and ascetical practice in Orthodoxy. This ranges from Orthodoxy's dramatic vision of salvation in Christ who tramples down death by death in order that He might lift up fallen Adam from the grave granting incorruption to the human race to the ascetical trajectory of all Orthodox living where the Christian is called to cut down the desires of the soul and the passion of the flesh with the sword of abstinence and water the wilderness with our tears and in this way come to shine with

\footnotetext{
90 ibid., 2.8, p.13.

91 Nikitas Stithatos, 'On Spiritual Knowledge, Love and the Perfection of Living: 100 Texts' in The Philokalia, 4: $\S \S 41-42$, p.150.

92 See Dorotheos of Gaza, 'I: On Renunciation' in Discourses and Sayings, trans. Eric P. Wheeler (Kalamazoo, Mich.: Cistercian Publications, 1977), p.85.

93 Nikitas Stithatos, 'On Spiritual Knowledge', §43, p.151.

94 ibid., §44, pp.151-152.
} 
the uncreated light of repentance. In this last section, I want to point out just a few key ways that theosis is described in the tradition. These are: (a) adoption; (b) incorporation; and (c) transfiguration. All of these often but not always assume sacramental life, askesis and the practice of the contemplative Prayer of the Heart/Jesus Prayer or Hesychasm as the main tools for drawing close to God and taking on His freely offered divine life in Christ.

(a) We see the first aspect of theosis in the notion of adoption expressed succinctly in the hymnography of the Church: 'The dread council of Herod slew the young babes of old, filling Bethlehem with blood; while now Christ comes to the church to adopt many children through baptism.95 In Jesus Christ, Irenaeus of Lyons argued, we are saved through the 'paternal grace' 96 of the liberty of sonship. Our liberation is through our adoption in Christ by the Father as obedient sons insofar as Jesus Christ through His Spirit is 'saving us for the Father.' ${ }^{97}$ The Word who is the Son of God became the Son of Man who suffered on the cross so that we might be taken up into the life of the Word and receive adoption as sons of the eternal and everlasting Father which is the definitive means of our 'ascension to God'. ${ }^{98} \mathrm{He}$ writes, in a justly famous passage, that we are 'following the only true and firm Teacher, the Word of God, our Lord Jesus Christ, who, through His superabundant love, having become that which we are, in order that He might make us to be that which He is' ${ }^{99}$ This form of divinization, however, is not the loss of humanity, but its renewal and transformation by the Father's Spirit in Jesus Christ who is God as the true living man, so that Irenaeus can write that

95 Compline, Canon Ode III, Forefeast of Theophany (3 January), Menaion, trans. Archim. Ephrem (Lash), Found at <http://newbyz.org/lashmenaion.html\#_Toc102863610> (last accessed: 8 August 2018).

96 Irenaeus, $A H$ 4.36.4.

97 Irenaeus, Dem 38.

98 Irenaeus, $A H$ 3.19.1.

99 ibid., 5.pref. 
'where the Spirit of the Father is, there is a living man'. ${ }^{100}$ In short, humans are to 'become partakers of the divine nature' (2 Pet. 1:4), adopted sons and daughters of God, as Cyril of Alexandria says, 'through grace by imitation'. ${ }^{101}$ This in no way makes us gods by nature, for the creature is not its Creator. The uncreated and the created are different, but, as we argued earlier, forever exist in a creative tension. God has freely chosen to be God with the world to which he has bound himself. A starker difference from the pantheism of Mangodhood could not be imagined.

(b) The next aspect of theosis found in the Eastern Orthodox tradition is what might be called incorporation and it involves a sort of "gracious switcheroo" (or 'marvellous exchange' or 'mingling' of divine and human) between divinity and humanity, richness for poverty, as we see in one Byzantine hymn: 'That you might make those born of earth partakers in the divine nature, you took our flesh from the Virgin, and became poor. Holy are you, O Lord!' 102 Here the idea is that God graciously condescends to become a human being, becoming, as Maximus the Confessor put it, a human being for the sake of human beings and by exchanging His condition for our broken human condition reveals the power that elevates humanity to become God through his love for God and thereby brings God down to become a human being because of God's great love for humanity: 'by this blessed exchange, it renders God man by reason of the divinization of man, and man by reason of the Incarnation of God. For the Logos of God (who is God) wills always and in all things to accomplish the

100 ibid., 5.9.3.

101 Cyril of Alexandria, 'Commentary on John' in Cyril of Alexandria, ed. and trans. Norman Russell (London/New York: Routledge, 2000), I.9, 89c, p.101.

102 Oktoechos/Paraklitiki, Canon of the Theotokos at Matins on Sunday, Ode III, Tone Three, Trans. Archim. Ephrem (Lash), Found at <https://web.archive.org/web/20160322163734/http://anastasis.org.uk/sun3mc.htm> (8 August 2018). 
mystery of His embodiment.' 103 The divinization of humanity is radical such that, as Symeon the New Theologian puts it:

We are made members of Christ, and Christ becomes our members, And Christ becomes my hand and the foot of all wretched me, And wretched I become the hand of Christ and the foot of Christ. I move my hand and my hand is Christ entire.

For, understand me, the divine divinity is indivisible! ${ }^{104}$

Symeon then makes a famous radical conclusion. If we are united with God in Christ then this means that not only my hands and feet are those of God in Christ but even those parts considered most shameful:

For while we become many members He remains one and indivisible, and each part is the whole Christ himself,

And so thus you will know that both my finger and my penis are Christ. ${ }^{105}$

Once again we see with this revelling in the holiness of materiality a radical difference from transhumanism which has a Gnostic disdain for the body which it wishes to leave behind in the transformation of biotech.

(c) The last aspect of theosis is Transfiguration or Metamorphosis. The main symbol of this is Christ's resplendent change and showing forth of His Godhead on Mt Thabor (cf. Mk. 9:2-8 and 2 Pet. 1:16-18). Here in the hymnography of the Forefeast of the Transfiguration it speaks of human nature in Christ - and we in Him - being 'refigured with the fire of the Godhead' so that it blazes with 'incorruption as at first.' 106 We are then called to ascend the holy mountain with the disciples to behold the Transfiguration of the Lord seeing the Law and the Prophets, Moses and Elijah flanking him, and hearing the Father bearing witness to Him as the 'chosen Son' so that we can

103 Maximus the Confessor, 1: Amb. 7 (PG 91.1084C-D), p.107.

104 Symeon the New Theologian, Divine Eros: Hymn of St Symeon the New Theologian, Daniel K. Griggs, ed. (Crestwood, NY: St Vladimir's Seminary Press, 2010), Hymn 15, 11.141-145, p.87.

105 ibid., Hymn 15, 11.158-160, p.87.

106 Aposticha of Matins of the Forefeast of the Transfiguration (5 August), trans. Archim. Ephrem (Lash), <https://web.archive.org/web/20160322212715/http://anastasis.org.uk/5_august.htm> (last accessed: 8 August 2018). 
worship Christ aright and say 'You alone are our God, who became incarnate and made the human divine': ${ }^{107}$

You were transfigured in glory on Mount Tabor, O Christ God, revealing the glory of your divinity to your disciples, in order to illumine us with the light of your knowledge, and to guide us in the path of your commandments, since you alone are Good and the Lover of humankind. ${ }^{108}$

The 'uncreated divine light' is the Holy Spirit and its experience through the 'spiritual senses' is at the heart of hesychasm or the tradition of the 'prayer of the heart' in Eastern Orthodoxy.

The classic example in hagiography of theosis as transfiguration is 'A Conversation of St Seraphim of Sarov with Nicholas Motovilov Concerning the Aim of the Christian Life.' In this work, the celebrated Russian spiritual teacher and practitioner of hesychastic prayer St Seraphim of Sarov (1754 (or 1759)-1833) has a dialogue in the middle of winter in the woods deep with snow with his disciple, Motovilov (1809-1879). Seraphim tells Motovilov that the end of the Christian life is 'to acquire the Holy Spirit of God.' ${ }^{109}$ Seraphim says to Motovilov, appealing to his experience as a merchant, that Christians in acquiring the Spirit (through prayer, almsgiving, vigils, fasts etc.) which is grace-giving and eternal are like smart business people who acquire money as capital for future investment. Virtuous acts performed for the sake of Christ confer on them the grace of the Holy Spirit which enters their souls just as selling earthly goods attains capital for the businessman. ${ }^{110}$ The fire of the grace of the Holy Spirit which is like light 'prepares in our soul and body a throne for the all-creative presence of God.' ${ }^{111}$ Motovilov asks: 'How am I to know whether He

107 ibid.

108 Doxastikon at the Aposticha of Vespers of the Forefeast of the Transfiguration (5 August), trans. Gregory Tucker (thanks to the translator for sharing it with me).

109 'A Conversation of St Seraphim of Sarov with Nicholas Motovilov Concerning the Aim of the Christian Life' in The Spiritual Instructions of Saint Seraphim of Sarov, ed. Franklin Jones (Los Angeles: The Dawn Horse Press, 1973), p.42.

110 ibid., pp.44-45.

111 ibid., p.46. 
is with me or not?'112 Seraphim then takes Motovilov firmly by the shoulders so he too can see and experience the divine Spirit as he, Seraphim, sees Him all the time: 'We are both together, son, in the Spirit of God! Why lookest thou on me?' Upon being touched by Seraphim, Motovilov claims he immediately saw Seraphim and then himself, like Moses (Ex. 34: 29-35) descending from Horeb, Christ on Thabor and numerous Desert Fathers, shining with uncreated divine light or divine energies: "I cannot look, father, because lightning flashes from your eyes. Your face is brighter than the sun and my eyes ache in pain!", Father Seraphim said: "Fear not, my son; you too have become as bright as I. You too are now in the fullness of God's Spirit; otherwise you would not be able to look on me as I am." 113

Godmanhood is about holiness. The holiness of real people called to become gods by grace. The divinization of Mangodhood, of transhumanism, in contrast, has no moral telos and sees individual persons as simply different algorithmic patterns of data, information that might just as well be uploaded to a computer. It cannot fathom holiness. It cannot imagine a vision of God. It cannot see anything but itself.

So we see three common aspects of theosis in Eastern Orthodoxy as the religion of Godmanhood: (a) adoption; (b) incorporation; and (c) transfiguration. These are usually found together, often in a sacramental context, and, though their context is certainly initially monastic, they are not said to be the special province of monastics but offered to all lay people in catechesis as their calling if they only take on the askesis or discipline of the Christian life. But theosis is all pervasive. In drinking of the Spirit, each person is said to become every day more conformed to the divine-human life of 
Christ by the loving will of the Father which is at its very simplest, what it is to be a Christian: a son and daughter of God by the Son of glory.

\section{Conclusion}

When one goes beyond the Satanic ruse of transhumanism one finally arrives at a profound realization about technology. Technology is not simply about dishwashers, toasters and memory sticks but about truth as a way of revelation, almost selfrevelation: 'Technology is therefore no mere means. Technology is a way of revealing. If we give heed to this, then another whole realm for the essence of technology will open itself up to us. It is the realm of revealing, i.e., of truth. ${ }^{114}$ If technology is about a sort of revelation, a type of revealing of a reality beneath the things themselves, then what is revealed? Is there a 'personal' reality revealing itself in the disturbing new advances in biotech? I don't think it is Being, Heidegger's detheized finite G/god, as this is simply a personal mythology of the philosopher. It cannot be a self-revelation of God as Holy Trinity in Christ, the religion of Godmanhood, as transhumanism is Satanic, but what we see with biotech, the religion of Mangodhood, is a complete obliteration of the creature as creature and God as God. So maybe, short of biotech revealing a malevolent deity, there is no divine self-revealing happening here other than a sort of holding up of the mirror to humanity so that it can Dorian Grey-like see its own awful image as Übermensch. Thus, if transhumanism reveals anything it is simply the things themselves as they really in their our relationship to us defined entirely by our own power over them which is our power to manipulate them and us endlessly unto Kingdom come. So what we see with human biotechnological enhancement is the revelation of the horror of our own autodivinization, our Mangoodhood, how we have

114 Martin Heidegger, The Question Concerning Technologyand Other Essays. Trans. William Lovitt (NY: Harper \& Row, 1977), p.12. 
transformed ourselves into an oversized and disembodied brain like IT in L'Engle's $A$

Wrinkle in Time :

A disembodied brain. An oversized brain, just enough larger than normal to be completely revolting and terrifying. A living brain. A brain that pulsed and quivered, that seized and commanded. No wonder the brain was called IT. IT was the most horrible, the most repellent thing she had ever seen, far more nauseating than anything she had ever imagined with her conscious mind, or that had ever tormented her in her most terrible nightmares. 115

But there is another path and another vision than this nightmare: the pre-modern and pre-humanist vision of Godmanhood. It is to be hoped that this vision splendid might become more widely known and serve as a sort of check on the Luciferian fantasies of Mangodhood seen in contemporary transhumanism. But such a project of the dialogue of the ancient wisdom of Eastern Orthodoxy with modern technology has yet to be initiated although on it perhaps stands the hopes of our age.

115 Madeleine L'Engle, A Wrinkle in Time (NY: Dell, 1962), p.158. 